\title{
The Remains of Exceptionalism in Criminal Law
}

\author{
Francesco Viganò ${ }^{1}$
}

Accepted: 15 September 2021 / Published online: 26 September 2021

(c) The Author(s) 2021

Is criminal law "exceptional"? In other words: is criminal law essentially different from any other branch of the law, being governed by special—indeed, unique — principles, different from those underlying the remaining parts of the legal system?

My answer is: perhaps criminal law was exceptional —at least, the standard doctrinal opinion used to assume that it was. However, such an assumption is hardly convincing today.

\section{What Makes Criminal Law Different? Some "Classic" Assumptions}

The usual narrative about criminal law being "different", or "unique", points at three essential features.

The first one is the very special burden on individual rights imposed by criminal sanctions.

In Europe, as in many parts of the world, the horror of the death penalty has been almost wiped out. But even here, imprisonment as a criminal sanction still flourishes-even in its harshest form of life imprisonment, which in some jurisdictions actually means, in some cases, imprisonment until the prisoner's death.

An essential characteristic of imprisonment is the intense suffering caused to the convict-a suffering which involves, above all, his bodily dimension. The very fact that the State, as a public authority instituted with the aim of reducing and controlling intersubjective violence among its citizens, cold-bloodedly inflicts such a harm on one of its citizens obviously requires a strong justification-much stronger than that which is needed to justify other measures, impinging on less "existential" individual rights, or causing a far lesser degree of suffering to the individual affected.

Somewhat less obvious, but also widely shared among scholars, is the assumption that criminal sanctions are unique because of their expressive character.

Francesco Viganò

francesco.vigano@unibocconi.it

1 Bocconi University, Milan, Italy 
Punishment is different from other penalties - so the argument goes-because it conveys a special stigma: i.e. a formal, solemn disapproval by the community as a whole of the conduct for which punishment is imposed. And this social disapproval is thought to profoundly affect the moral status of the person within the community. Which, in its turn, calls for a special justification.

The reasons for the social and/or moral condemnation implied in a criminal conviction-already in a criminal conviction as such, independently of the subsequent imposition of a punishment causing actual bodily suffering - are various.

A first standard assumption is that the special stigma involved in punishment is primarily based upon the special nature of the harm caused by the offence. The precise identification of this harm varies, of course, depending on the general theory of criminal law embraced by each scholar. A commonly shared view in continental legal systems - in Italy and Germany, for example - is that criminalisation is legitimate (a) insofar as it targets courses of conduct that are actually or potentially harmful to legally protected interests (Rechtsgüter, beni giuridici), which exist prior to, and independently from, criminalisation itself, and are not identical with mere moral values, taboos, feelings or vague requirements of fairness in intersubjective relations, ${ }^{1}$ which might be the legitimate target of non-criminal sanctions. Moreover (b), criminalisation is legitimate only insofar it proves necessary to protect these interests, other less intrusive sanctions being demonstrably insufficient to this aim (ultima-ratio, or "subsidiarity" principle). ${ }^{2}$ Other scholars, particularly in the AngloSaxon world, stress instead the importance of the core values protected by criminal law and criminalisation choices, by insisting on their belonging among those that are indispensable to cement the peaceful coexistence of the society: the underlying idea is, here, that the commission of an act denying those values necessarily calls for a counter-message solemnly signalling the (public) wrongfulness of that act, and at the same time reaffirming the value at stake. ${ }^{3}$

On the other hand, even those who-like the majority of continental scholarssee the essential aim of criminal law as the protection of "social interests" in their objective dimension, agree that criminal punishment also requires a subjective element underlying the offender's behaviour: that is, his mens rea (intention or knowledge, sometimes recklessness or at least some form of negligence) plus the absence of abnormal situations that might have affected his capacity to understand the significance of his behaviour, and/or to act in compliance with the law. None of these requirements is a precondition for the imposition of other forms of sanction, where personal blame (in the specific sense of subjective fault) is not a necessary requirement, and the objective harmfulness of the behaviour-i.e., the actual causation of

\footnotetext{
${ }_{1}$ For a recent and comprehensive explanation of the Rechtsgüterschutz-doctrine in Germany, which is today hugely influential in numerous other jurisdictions, see Klaus Roxin and Luís Greco, Strafrecht Allgemeiner Teil (München: C.H. Beck, 5th edn. 2020), pp. 26-62.

2 Roxin and Greco, n. 1 above, pp. 86-90.

3 See, for example, Antony Duff, "Criminal Law and the Constitution of the Civil Order", University of Toronto Law Journal 70(1) (2020): 4, pp. 13-16.
} 
a state of affairs that is inconsistent with that envisaged by the law-may well be a sufficient basis for their imposition.

But there is more. The public stigma associated with a criminal conviction is typically conveyed through a legal proceeding — the public trial-which is highly ritualised. Indeed, the trial is conceived as a public event designed to heal the wound inflicted by the criminal offence on the public and the individual victim. This ritual—which has much in common with a religious celebration, albeit conducted "in the name of the people" instead of God's-has a nearly hieratical connotation that is unknown to other forms of proceeding leading to the imposition of non-criminal sanctions, which are usually conducted in a much more informal way, often without a hearing at all (at least when it comes to mere administrative sanctions).

Both those previous features-exceptional burdensomeness and stigma-are, unsurprisingly, thought to require a special constitutional status, in order to set strict limits to the State's punitive powers. Such limits historically drew their raison d'être from the awareness that the most blatant abuse of power by governments against their opponents often takes place not by secret assassinations, but through formal criminal trials, by which Leviathans of all sorts seek to publicly legitimise what would otherwise appear as sheer use of violence.

These limits include, first and foremost, a stricter principle of legality than that governing any other public power potentially impinging on individual rights. The nullum crimen, nulla poena sine lege principle is read here as an absolute ban on retroactive provisions, which are usually allowed-at least to a certain extent and under certain conditions - in other areas of law. Moreover, the principle of legality in criminal matters is interpreted everywhere as requiring a high degree of precision in the definition of the courses of conduct that are subject to punishment, in order to curtail the discretion exercised by juries and courts, enhance the role of democratically legitimised parliaments, and grant individual foreseeability to the addressees of the criminal law as to the possible consequences of their acts. ${ }^{4}$ And finally, most legal systems construe in a restrictive way the concept of "law" (lex) to which "nullum crimen" refers, by limiting its scope to the lex parlamentaria, or at least to statutes with the same hierarchical status as primary law.

Another set of constitutional limits contained in every charter of rights-starting at least from the English Bill of Rights of 1689-concerns the ban on certain kinds of punishment: "cruel and unusual" punishments in the older charters; "excessive fines" and/or the confiscation of the totality of assets of the convict and his family; and, in more recent times, the death penalty or even "disproportionate" punishments. ${ }^{5}$ Some national Constitutions (such as the Italian or the Spanish) set forth, moreover, a positive indication to legislators, judicial actors and prison authorities,

\footnotetext{
4 Among others, Alice Ristroph, "An Intellectual History of Mass Incarceration", Boston College Law Review 60(7) (2019): 1949, p. 1954.

5 Article 49 (3) of the European Charter.
} 
according to which punishments should pursue-alongside other legitimate goalsthe rehabilitation of convicts.

Last but not least, every constitution-starting from the most ancient onesincludes a number of key procedural provisions, when it comes to criminal law. Such provisions already apply to the very beginning of the investigations potentially leading to charge, conviction and sentence: to the police powers of search and seizure, and nowadays to intercept communications, which are generally permitted only under judicial supervision. Furthermore, the powers to arrest and hold a person in custody are subject to habeas corpus controls by judicial authorities; and a whole set of "fair trial rights" assist the defendant, in order to grant her a full and effective chance to defend herself and minimise the risk of wrongful conviction.

On the other hand, at least in one respect the special constitutional status of criminal law has long been strikingly less effective than constitutional constraints have been in other branches of the law. The choices about criminalisation themselves, as well as the choices of the punishments for criminalised behaviour, have usually been substantially immune to any serious judicial review, even among courts that do exercise, in general, a pervasive judicial review of the constitutionality of legislation in other branches of law. The underlying idea was that choices about what behaviour to criminalise, as well as about how (and how much) to punish it, are essentially political choices, which have to be respected by courts.

\section{Questioning the Classical Assumptions}

None of these three features that are supposed to give criminal law its "exceptional" character — burden, stigma and special constitutional status—stands up to a closer analysis based not on some ideal picture of the criminal law as it should be, but on what criminal law really is, or at least has now become.

Admittedly, it cannot be disputed that criminal sanctions still retain the highest potential to impinge on the most intimate sphere of basic human rights, such as life, body, personal liberty; and that their consequences can indeed be dramatic for the individual concerned. But at least two considerations undermine the very foundations of the idea that criminal law is "exceptional".

On the one hand, not all criminal sanctions produce such a dramatic impact. ${ }^{6}$ Indeed, a significant proportion of the sentences that are actually imposed in many legal systems do not even imply deprivation of personal liberty. Just to give two European examples: in Germany, an overwhelming number of sentences consist of fines; in Italy, where fines are also often applied but—oddly enough—not enforced, sentences of up to four years imprisonment imposed to non-recidivists are regularly suspended, or-in more serious cases—replaced with other less intrusive measures,

\footnotetext{
${ }^{6}$ Christoph Burchard, Die Konstitutionalisierung der gegenseitigen Anerkennung (Frankfurt: Vittorio Klostermann, 2019), p. 42.
} 
such as control orders or (less commonly) community service. Criminal fines and administrative fines, of course, differ in that the former can be converted into sanctions affecting personal liberty, including imprisonment; but this possibility—purely theoretical in Italy - is everywhere rarely actualised, so that the impact of fines on the individual affected is hardly distinguishable from that of other pecuniary sanctions, including civil damages.

On the other hand, and even more remarkably, the impact of non-criminal penalties on individual fundamental rights has been growing everywhere in the world throughout the last decades. Think of the impact of certain forms of administrative or civil forfeitures, which can potentially deprive the individual of the totality of her assets, if a court - applying a civil standard of proof-considers those assets as instrumental to, or derived from, the commission of offences not previously proven in a criminal trial. Or consider the number of restrictions of personal liberty implied in a civil injunction imposed by an English court-but similar examples can be found in many other legal systems - aimed at preventing future criminal behaviour by the individual concerned. Not to mention the non-criminal measures that totally deprive the person of his personal liberty, such as the administrative detention of aliens pending deportation, or the forms of preventive detention of dangerous persons, with or without a previous conviction.

All these measures are likely to cause-much like many 'nuclear' criminal sanctions-intense suffering to the persons affected. Moreover, many-if not all—of these measures share "punitive" purposes with the proper criminal sanctions, such as deterrence, incapacitation, and possibly retribution, in as far as they also inflict suffering in response to wrongful behaviour, often requiring as well that such behaviour be committed with some mental element.

As to the communicative function of criminal law, the special stigma traditionally associated with criminal conviction is currently being weakened by several factors.

To begin with, the reality of criminal law systems is very distant from the ideal picture of a "nuclear" criminal law, solely concerned with serious offences affecting fundamental individual rights and the essential conditions of the "king's peace". Not only have mere regulatory offences and petty misdemeanours played a great role in criminal systems in every time and place, ${ }^{7}$ a fact that is often overlooked by the standard scholarly opinions; recent legislative trends also tend to intensively expand the criminalisation of mere preparatory acts, well beyond the traditional realm of inchoate offences, with a view to preventing the actual occurrence of harm, especially when facing the threats posed by organised crime and terrorism. These trends deeply undermine the very concept of criminal law as a public and solemn response to the causation of harm, and load it instead with typical policing tasks, while enhancing the purely coercive character of sanctions (and pre-trial custody!)

\footnotetext{
${ }^{7}$ Ristroph, n. 4 above, p. 1965.
} 
as preventative tools, at the expense of its traditional backwards-looking character as a reaction to what has already happened in the past.

Even more significantly, the idea of stigma-and the underlying assumption of a reinforcement of collective values, realised through the public criminal conviction of the person having undermined them-becomes significantly diluted, as soon as one considers the overwhelming number of sentences which, in nearly every legal system, are not imposed as the outcome of a public trial, but are instead negotiated between prosecution and defence counsel, or pronounced at the end of a simplified proceeding held in camera, behind closed doors. The conviction fails, here, to convey any message to the public, simply because the public knows nothing, or very little, about it.

Finally, something also appears to be changing in recent years in respect of the alleged constitutional "exceptionalism" of criminal law. The main trend is, here, towards a "normalisation" of the relation between criminal law and constitutions ${ }^{8}$ (or human rights instruments).

To start with, there is a tendency among the highest courts throughout the worldwhether national or international - to extend the "criminal law" guarantees and principles set forth in constitutions and charters to those administrative and civil measures that share the same "punitive" character as the sanctions formally labelled as criminal. Such developments show a growing international consensus on the idea that, apart from stigma, what characterises a "punitive" sanction is both its character as a reaction to some past blameworthy infringement of the law, and-cruciallythe degree of its impact on the fundamental rights of the individual concerned, whose legitimacy must be carefully scrutinised by the courts, irrespective of the formal classification of the sanction by the legislator.

On the other side of the coin, another interesting trend is gradually emerging in some constitutional courts' case law. Legislative discretion in choices about criminalisation and punishments is more and more questioned, especially in respect of criminal provisions that interfere with the scope of protection of fundamental rights and liberties. This is what has happened, for example, in the recent decisions by the German and Italian Constitutional Courts that declared unconstitutional the existing criminal provisions about assisted suicide. ${ }^{9}$ In other cases not involving fundamental liberties, the Italian Constitutional court has annulled sentencing frameworks provided for some offences - not less important, in practice, than drug trafficking ${ }^{10}$ because of their disproportionate harshness in relation to the seriousness of the

\footnotetext{
${ }^{8}$ Christoph Burchard, "Strafverfassungsrecht—Vorüberlegungen zu einem Schlüsselbegriff", in Klaus Tiedemann, Ulrich Sieber, Helmut Satzger, Christoph Burchard, Dominik Brodowski (eds.), Die Verfassung moderner Strafrechtspflege (Baden-Baden: Nomos Verlag, 2016), 1, p. 37.

${ }^{9}$ German Constitutional Court, Judgment 2 BvR 2347/15; Italian Constitutional Court, Judgment $242 / 2019$.

${ }^{10}$ Italian Constitutional Court, Judgment 40/2019. In the same vein, see also Judgments 236/2016 and $222 / 2018$.
} 
offence, thereby disregarding the traditional deference reserved to legislative discretion in choices about how, and how much, to punish.

\section{Some (Tentative) Conclusions}

In the light of all this, the standard assumption that criminal law is "exceptional" seems hardly tenable today. ${ }^{11}$

As I mentioned before, this is not to say that criminal sanctions have become much milder than they were in the past, ${ }^{12}$ nor that they are identical with any other sanction within the legal order. Imprisonment and even-regrettably-capital punishment still have a formidable impact on millions of people's lives throughout the world. The ius puniendi continues to work as a ius terribile, albeit not in the extreme form that it used to take in the past.

Yet, the traditional dividing line between criminal and non-criminal sanctions is becoming more and more blurred. ${ }^{13}$ From a normative and institutional point of view, it is certainly still possible to clearly differentiate the two categories-the former being exclusively applied by criminal law actors (public prosecutors and criminal courts), the latter by other agencies. But from a material point of view, many criminal sanctions provided for regulatory offences are hardly distinguishable from their administrative or civil sanctions, whereas these latter have often acquired a "punitive" character, and dramatically impinge on fundamental rights, profoundly affecting the quality of life of the persons involved.

Faced with this reality, criminal scholars often advocate a return to the good old days of a "nuclear" - and "exceptional" - criminal law. And, as to the new reality of extremely harsh non-criminal sanctions, they either tend to ignore them, or simply brand them as illegitimate, in as far as those sanctions severely affect fundamental rights outside the sole constitutional framework - the criminal procedure-that could allow, in their opinion, such an effect to take place.

Frankly, I am not sure that this is a sensible response.

To begin with, the good old days of a "pure", "nuclear" criminal law probably never existed: criminal legislation and its administration have always been full of petty offences at the disposal of police forces, enabling them to exercise control over marginalised sectors of the population. ${ }^{14}$

What is (relatively) new is, admittedly, the emergence of a new generation of non-criminal sanctions and measures that severely impinge on basic fundamental rights, which definitely deserve much more attention by legal scholars. There is in fact a great risk associated with the current shift from traditional criminal law

\footnotetext{
11 I therefore fully agree, in this respect, with Burchard, n. 6 above, p. 42.

12 As Urs Kindhäuser seems to imply in his much-discussed paper "Straf-Recht und ultima-ratio-Prinzip", Zeitschrift für die gesamte Strafrechtswissenschaft, 129(2) (2017): 382.

13 See, for example, Issachar Rosen-Zvi and Talia Fisher, "Overcoming procedural boundaries", Virginia Law Review 94(1) (2008): 79, p. 82.

14 Ristroph, n. 4 above, p. 1960.
} 
punishments to non-criminal sanctions, since the latter provide State agencies with a massive coercive potential, without the constitutional and human rights constraints that are applicable to criminal law and criminal process ${ }^{15}$ — which is precisely the reason why they have become so popular among so many legislators throughout the world.

Criminal law scholars - as well as supreme and constitutional courts-should probably become more aware of this reality. Whether we like it or not, criminal policy is more and more carried out by law enforcement agencies through a variety of tools, among which criminal law is just one of the pieces of a more complex puzzle. Criminal policy today involves numerous other administrative or "civil" measures like those mentioned above (asset forfeiture, civil injunctions): some share a punitive character, others are purely preventive; all aim at the same goal-reducing the occurrence of criminal behaviour within the society; all affect, to a greater or lesser extent, the fundamental rights of the individuals involved.

The proper response to this reality, for those who care about fundamental rights, should arguably be a renewed effort to ensure and strengthen effective protection of those rights in relation to all measures impinging on them-be they criminal or non-criminal. As for criminal measures stricto sensu, a deeper judicial review is probably needed, through a wider application of the general principles-such as proportionality - setting limits to State's interventions, without holding back from exercising this control out of a sense of respect for the "political" nature of the choices underlying criminalisation and punishment, as courts used to do until quite recently. On the other hand, constitutional criminal law guarantees should be further extended to non-criminal measures having a "punitive" character, particularly where their impact on fundamental rights is comparable to that produced by criminal punishments.

Probably, the golden rule should be this: the more important the right impinged upon by a measure, and the more serious the restriction of the right caused by it, the higher should be the constitutional threshold that must be met in order to justify the measure, regardless of its formal nature.

After all, the effective protection of fundamental rights cannot, and should not, depend on labels.

\section{Discussion}

A number of contributions in this special issue, among them those of Matravers and myself, have cast doubts on the alleged 'exceptionality' of criminal law by pointing out that some of the features that are usually mentioned to support this characterisation are common to other branches of law as well.

This is especially evident with regard to the burdens instinctively associated with criminal law: while it is undeniable that criminal punishments typically affect

${ }_{15}$ Rosen-Zvi and Fisher, n. 13 above, p. 83. 
personal liberty (or even life, where the death penalty is still in force), it appears that administrative, family, immigration law-to mention but a few examplescan also have a powerful, indeed disruptive, impact on the individual's fundamental rights. As I mentioned in this paper, such an impact has probably grown over the last decades, namely because of a legislative tendency, which can be observed in many continental and Anglo-Saxon systems, to introduce civil or administrative measures designed to tackle criminality, such as civil forfeiures or administrative sanctions for serious market abuse, so as to avoid the constitutional constraints that characterise criminal sanctions.

Remarkably, many of these measures trigger police powers that are just as coercive as those triggered by criminal law. Think about deportations of immigrants, child-care proceedings, forced hospitalisation of mentally ill patients, eviction of tenants, civil forfeitures, and the like. Therefore, Willenman's point that criminal law is closely linked to coercive police actions is per se correct but does not identify, in my eyes, a distinctive feature of criminal law.

Some of the papers in this special issue have argued, moreover, that the very idea of 'exceptionalism' often works as a legitimising factor: either for criminal law as a whole- 'exceptionalism can make a world without criminal law unthinkable', according to Ristroph; or at least for the expansion of criminal law pursued by current populist agendas, as argued by Burchard, the latter effect being based on the claim that when some key values are at stake, the recourse to criminal law is seen as of course justified, since 'nothing else will do' to protect those values.

According to both Ristroph and Burchard, the narrative of a public censure implicit in punishment-one of the 'exceptional' features that, beyond burdens, allegedly characterise criminal law-often seems to offer a plain and self-sufficient explanation of why criminal law is needed, say, to protect the 'sanctity of life' (with respect to abortion or end-of-life matters, according to some pro-life political agendas) or 'human dignity' (with respect to a variety of issues, ranging from motherhood surrogacy to prostitution, hate speech, denial of genocide, etc.). The trump card that 'super-values' are at stake seems to curtail any need for further discussion about the proportionality of the choice of criminalisation, and for a more detailed analysis of benefits and costs of that choice, for both the community and the individual(s) concerned.

I confess that I am not sure whether a community can really survive without criminal law. I tend to think that some form of physical coercion, as well as the threat of physical coercion that is implied in criminal provisions and appeals to individual responsibility (a hallmark of criminal law as distinct from other modes of enforcement, according to Duff and Marshall's 'classical' model), are indeed indispensable means to contain intersubjective violence and protect the more vulnerable members of society, without prejudice to the possibility of putting in place, wherever possible, new (and less harsh) strategies to cope with interpersonal conflicts, such as restorative justice.

However, I fully agree with Burchard's view of exceptionalism as a driving factor in the expansion of criminal law, well beyond the limits of what can reasonably 
be considered necessary and proportionate to those aims. I would just add a brief remark on this point, from my particular perspective as a current member of a constitutional court.

One of the alleged exceptional—or, if you wish, 'distinctive' — features of criminal law I have identified in my paper is its special constitutional status, i.e. the existence, in every constitution or charter of rights, of a set of guarantees specifically tailored to criminal law, criminal process and criminal punishment.

At the same time - and this is something which is often overlooked by scholars- the usual judicial practice of reviewing legislation tends to be highly deferential towards legislative choices in criminal matters. This is arguably due to a sense of respect for the sovereignty of parliament in making the crucial assessments as to what behaviour deserves to be treated as a crime, and consequently as to whether a member of the community, after being held responsible for that behaviour, deserves to be solemnly censured, and subjected to the deprivation of his or her most fundamental rights. The current understanding of the legality principle is that it is a task for the community, through its democratically elected representatives, to identify criminal behaviour, and to provide the appropriate punishments for the perpetrator. Accordingly, courts should not be allowed to second-guess those choices.

As a result, the supposed exceptionality of criminal law-in this case, its constitutional exceptionality-flows into shielding criminal legislation from the same level of scrutiny as is carried out by courts which are charged-as in the US, Canada and in most European countries — with the task of judicial review of legislation. Even if it is not a positive factor in the expansion of criminal law, this constitutional exceptionalism reveals itself as a largely useless tool to set any kind of judicially enforceable constraints on populist agendas.

I cannot but agree with Burchard, then, on his final proposal to de-exceptionalise criminal law, as a means of de-escalating it.

This is abundantly clear also from my particular point of view. What really matters, from a constitutional perspective, is how a given measure infringes upon a person's fundamental rights. Criminal provisions usually (albeit not always) have an enormous impact on their addressees' fundamental rights. For this reason-and not simply qua criminal provisions - they should undergo a particularly strict scrutiny, as regards their constitutional legitimacy (at a national level) and as regards their compatibility with human rights standards (at an international level), just like any other measure having a similar impact, whatever their formal nature might be.

Therefore, one of the features of the (constitutional) principle of legality in criminal matters according to its continental understanding - the idea of a prerogative for the community to determine what behaviour deserves a criminal sanction-should no longer be invoked by the courts as a pretext for not thoroughly reviewing the sustainability of legislative decisions in these matters, since every criminalisation choice has an impact on fundamental rights. And fundamental rights should be protected even against the will of the community. 
In such reviews, 'sanctity of life' or 'human dignity' arguments must not function as trump cards to declare any discussion moot, but instead-at the very most-as starting points for the analysis of proportionality. Protection of the sanctity of life or human dignity may well be invoked as legitimate aims for criminal provisions (even if a more nuanced rationalization of any single provision would obviously be preferable); but a further, and decisive, examination will be needed as to whether the means put in place by that provision bear a rational connection to those aims, whether criminalisation can be replaced with less intrusive means, and whether the legislator struck an overall fair balance among the competing interests, taking into account also the collateral costs of criminalisation. This has to follow the "normal" standards that courts usually adopt in the proportionality review of legislation.

What we need is, ultimately, a 'de-exceptionalisation'-i.e., a 'normalisation' of constitutional law in respect of criminal matters, in order to protect fundamental rights more effectively.

Acknowledgments Francesco Viganò grateful to the participants in the Political Turn(s) in Criminal Law Theory Workshop in July 2020 for their insightful comments on a very rough draft version of this paper.

Funding Open access funding provided by Università Commerciale Luigi Bocconi within the CRUICARE Agreement.

Open Access This article is licensed under a Creative Commons Attribution 4.0 International License, which permits use, sharing, adaptation, distribution and reproduction in any medium or format, as long as you give appropriate credit to the original author(s) and the source, provide a link to the Creative Commons licence, and indicate if changes were made. The images or other third party material in this article are included in the article's Creative Commons licence, unless indicated otherwise in a credit line to the material. If material is not included in the article's Creative Commons licence and your intended use is not permitted by statutory regulation or exceeds the permitted use, you will need to obtain permission directly from the copyright holder. To view a copy of this licence, visit http://creativecommons.org/licen ses/by/4.0/.

Publisher's Note Springer Nature remains neutral with regard to jurisdictional claims in published maps and institutional affiliations. 